\section{Subtle Structural Changes in Coordination Chains: Influence of the Flexibility of the Precursor Ligands and of the Solvent}

Cui-Juan Wang, ${ }^{\dagger}$ Hai-Rui Ma, ${ }^{\dagger}$ Yao-Yu Wang,,${ }^{\dagger}$ Ping Liu, $^{\dagger}$ Li-Jun Zhou, ${ }^{\dagger}$

Qi-Zhen Shi, ${ }^{\dagger}$ and Shie-Ming Peng ${ }^{\dagger}$

Department of Chemistry \& Shaanxi Key Laboratory of Physico-inorganic Chemistry, Northwest University, Xi'an 710069, P. R. China, and Department of Chemistry, National Taiwan University, Taipei, Taiwan

Received March 13, 2007; Revised Manuscript Received June 6, 2007
CRYSTAL

GROWTH

$\mathcal{E}$ DESIGN

2007

VOL. 7,NO.9

$1811-1817$

\begin{abstract}
A novel flexible ligand dpap $2 \mathrm{H}_{2} \mathrm{O}(\mathbf{1})\left(\right.$ dpap $=2,6-\left(N, N^{\prime}\right.$-di(4-pyridyl)amino)pyridine) and its five related coordination polymers $\left\{\left[\mathrm{Cu}(\mathrm{dpap})(\mathrm{OAc})_{2}\right] \cdot \mathrm{CH}_{3} \mathrm{CN}\right\}_{n}\left(\mathbf{2} \cdot \mathbf{C H}_{\mathbf{3}} \mathbf{C N}\right),\left\{\left[\mathrm{Cu}(\mathrm{dpap})(\mathrm{OAc})_{2}\right] \cdot 0.25 \mathrm{CH}_{2} \mathrm{Cl}_{2}\right\}_{n}\left(\mathbf{2} \cdot \mathbf{0 . 2 5} \mathbf{C H}_{2} \mathbf{C l}_{2}\right),\left\{\left[\mathrm{Cu}(\mathrm{dpap})(\mathrm{OAc})_{2}\right] \cdot \mathrm{CHCl} 3\right\}_{n}$ $\left(\mathbf{2} \cdot \mathbf{C H C l}_{3}\right),\left\{\left[\mathrm{Cu}(\mathrm{dpap})(\mathrm{OAc})_{2}\right] \cdot 0.5 \mathrm{CH}_{3} \mathrm{OH}\right\}_{n}\left(\mathbf{2} \cdot \mathbf{0 . 5} \mathbf{C H}_{\mathbf{3}} \mathbf{O H}\right)$, and $\left\{\left[\mathrm{Cu}(\mathrm{dpap})(\mathrm{maa})_{2}\right] \cdot 2 \mathrm{CH}_{3} \mathrm{OH}\right\}_{n}(\mathbf{3} \cdot \mathbf{2} \mathbf{C H} \mathbf{O H})(\mathrm{Hmaa}=2-\mathrm{methyl}-$ acrylic acid) have been synthesized and structurally characterized by X-ray crystallography. The networks showed a lack of dependence on the nature of the counterion and solvent. Compound $\mathbf{2} \cdot \mathbf{C H}_{\mathbf{3}} \mathbf{C N}$ consists of uncoordinated guest $\mathrm{CH}_{3} \mathrm{CN}$ molecules and a onedimensional (1D) zigzag chain. The diffusion in the $\mathrm{CH}_{2} \mathrm{Cl}_{2}$ solvent system results in a $1 \mathrm{D}$ helical chain of $\mathbf{2} \cdot \mathbf{0 . 2 5} \mathbf{C H} \mathbf{C} \mathbf{C l}_{\mathbf{2}}$, and that in $\mathrm{CHCl}_{3}$ system leads to a meso-helix chain $\left[\mathrm{Cu}(\mathrm{dpap})(\mathrm{OAc})_{2}\right]$ motif of $\mathbf{2} \cdot \mathbf{C H C l}_{\mathbf{3}}$. The overall structure of $\mathbf{2} \cdot \mathbf{0 . 5} \mathbf{C H} \mathbf{O} \mathbf{O H}$ was found to be similar to that of $\mathbf{2 \cdot 0 . 2 5} \mathbf{C H}_{\mathbf{2}} \mathbf{C l}_{\mathbf{2}}$ despite the presence of different solvent molecules. The volumes of the channels are as follows: $\mathbf{2} \cdot \mathbf{C H C l}_{\mathbf{3}}>\mathbf{2} \cdot \mathbf{0 . 2 5} \mathbf{C H}_{2} \mathrm{Cl}_{2}>\mathbf{2} \cdot \mathbf{C H}_{3} \mathbf{C N}>\mathbf{2} \cdot \mathbf{0 . 5} \mathbf{C H}_{3} \mathbf{O H}$. Using an maa group instead of an OAc ${ }^{-}$anion, we obtained polymer $\mathbf{3} \cdot \mathbf{2} \mathbf{C H}_{3} \mathbf{O H}$, which displays a topological meso-helix chain.
\end{abstract}

\section{Introduction}

The crystal engineering of coordination polymers aims to gain control of the topology and geometry of the networks formed through the judicious choice of building blocks, ${ }^{1,2}$ expanding itself by producing useful functions characteristic of a metalcomplex assembly. In particular, metal-organic frameworks (MOFs) have provided a new perspective on coordination chemistry, which occupy an important position as an alternative candidate for porous materials. ${ }^{3}$ The porous functions ${ }^{4}$ are, for instance, molecular adsorption and separation processes, catalysis, ion exchange, sensor technology, and optoelectronics. The recent upsurge of reports on porous MOFS has afforded compelling evidence for the ability to design and produce structures with unusual functionalities. ${ }^{5}$ Interestingly, host flexibility would be a key principle for high selectivity recognition, accommodation, and separation of a target molecule, which, at present, is regarded as a new class of practical materials. ${ }^{2}$ Up to now, several examples of discrete molecular assemblies have been found. ${ }^{6,7}$ However, reports on coordination polymers are relatively scarce. This is because flexibility in coordination polymers is incompatible with robustness necessary such that porous frameworks are maintained without guest molecules.

To create flexible porous frameworks, we first utilized ligand flexibility by introducing spacer substituents X(amino) in pyridyl groups, forming $p y-X-p y-X-p y$, in contrast to rigid rod $4,4^{\prime}-$ bipyridine. Second, we focused our attention on stacking and hydrogen-bonding interactions of the organic moieties. Here, the amide-containing (hydrogen-bonding sites) ligand 2,6- $\left(N, N^{\prime}\right.$ di(4-pyridyl)amino)pyridine (dpap) has been synthesized successfully and designed as a bridging ligand. Moreover, we have employed different counterions and solvents in our attempts to construct attractive coordination formation. In many previous examples, solvents were found to produce a dramatic effect on

* To whom correspondence should be addressed. Fax: +86-2988303798. E-mail: wyaoyu@nwu.edu.cn.

Northwest University.

$\doteqdot$ National Taiwan University. the extended structure of the network by acting as a coordination ligand or a template for the assembly process. However, the influence of the solvent in the formation of coordination polymers is poorly understood, and systematic studies of their role are relatively sparse. ${ }^{8-10}$ The arrangement of the ligand and consequent structural diversification were unanticipated given different anions and solvents incorporated in the networks. Despite the limits on the controllability of the resulting architectures, the structure diversity that is created allows opportunities to gain a better understanding of the factors that lead to this diversity, whereas the subtle changes in anions or solvents used for crystallization is also significant in MOFs. ${ }^{11}$ The consequent structural similarities of the networks appear to arise largely from the conformation of the ligand.

We report herein the synthesis, characterization, and crystal structures of five coordination polymers: $\left\{\left[\mathrm{Cu}(\mathrm{dpap})(\mathrm{OAc})_{2}\right] \cdot\right.$ $\left.\mathrm{CH}_{3} \mathrm{CN}\right\}_{n}\left(\mathbf{2} \cdot \mathbf{C H}_{3} \mathbf{C N}\right),\left\{\left[\mathrm{Cu}(\mathrm{dpap})(\mathrm{OAc})_{2}\right] \cdot 0.25 \mathrm{CH}_{2} \mathrm{Cl}_{2}\right\}_{n}$ (2 • $\left.\mathbf{0 . 2 5} \mathbf{C H}_{2} \mathbf{C l}_{2}\right),\left\{\left[\mathrm{Cu}(\mathrm{dpap})(\mathrm{OAc})_{2}\right] \cdot \mathrm{CHCl}_{3}\right\}_{n}\left(\mathbf{2} \cdot \mathbf{C H C l}_{3}\right),\{[\mathrm{Cu}-$ (dpap) $\left.\left.(\mathrm{OAc})_{2}\right] \cdot 0.5 \mathrm{CH}_{3} \mathrm{OH}\right\}_{n}\left(\mathbf{2} \cdot \mathbf{0 . 5} \mathbf{C H}_{3} \mathrm{OH}\right)$, and $\{[\mathrm{Cu}(\mathrm{dpap})-$ $\left.\left.(\mathrm{maa})_{2}\right] \cdot 2 \mathrm{CH}_{3} \mathrm{OH}\right\}_{n}\left(\mathbf{3} \cdot \mathbf{2} \mathbf{C H}_{3} \mathbf{O H}\right)$, which were obtained by tuning solvent mixtures.

\section{Experimental Section}

Reagents and Physical Measurements. All reagents and solvents employed were commercially available and used as received without further purification. Infrared spectra on $\mathrm{KBr}$ pellets were recorded on a Nicolet 170SX FT-IR spectrophotometer in the range $4000-400 \mathrm{~cm}^{-1}$. Elemental analyses were determined with a Perkin-Elmer model 240C instrument. FAB-MS mass spectra were obtained with a JEOL HX$110 \mathrm{HF}$ double focusing spectrometer operating in the positive ion detection mode. Thermal analyses was performed on a NETZSCH STA 449C microanalyzer with a heating rate of $10{ }^{\circ} \mathrm{C} \cdot \mathrm{min}^{-1}$ under air atmosphere.

Synthesis of dpap (1). 2,6-Diaminopyridine $(5.0 \mathrm{~g}, 45.8 \mathrm{mmol})$, $\mathrm{BuOK}$ (14.3 g, $127.7 \mathrm{mmol}$ ), and tris(dibenzylideneacetone)dipalladium $\left(\mathrm{Pd}_{2}(\mathrm{dba})_{3}\right)(2.0 \mathrm{~g}, 2.2 \mathrm{mmol})$ were added to a $200 \mathrm{~mL}$ flask under nitrogen. Then $100 \mathrm{~mL}$ of dry benzene and 4-chloropyridine $(14 \mathrm{~g}$, $11.7 \mathrm{~mL}$, and $123.3 \mathrm{mmol}$ ) were injected into the former solid, respectively, also under nitrogen. The resulting solution was stirred for $148 \mathrm{~h}$ under reflux. The product was filtered and washed three times 
Table 1. Crystal Data and Structure Refinements for $1,2 \cdot \mathrm{CH}_{3} \mathrm{CN}, 2 \cdot 0.25 \mathrm{CH}_{2} \mathrm{Cl}_{2}, 2 \cdot \mathrm{CHCl}_{3}, 2 \cdot 0.5 \mathrm{CH}_{3} \mathrm{OH}$, and $3 \cdot 2 \mathrm{CH}_{3} \mathrm{OH}$

\begin{tabular}{|c|c|c|c|c|c|c|}
\hline complex & 1 & $2 \cdot \mathrm{CH}_{3} \mathrm{CN}$ & $2 \cdot 0.25 \mathrm{CH}_{2} \mathrm{Cl}_{2}$ & $2 \cdot \mathrm{CHCl}_{3}$ & $2 \cdot 0.5 \mathrm{CH}_{3} \mathrm{OH}$ & $3 \cdot 2 \mathrm{CH}_{3} \mathrm{OH}$ \\
\hline empirical formula & $\mathrm{C}_{15} \mathrm{H}_{17} \mathrm{~N}_{5} \mathrm{O}_{2}$ & $\mathrm{C}_{21} \mathrm{H}_{22} \mathrm{CuN}_{6} \mathrm{O}_{4}$ & $\mathrm{C}_{19.25} \mathrm{H}_{19.50} \mathrm{Cl}_{0.5} \mathrm{CuN}_{5} \mathrm{O}_{4}$ & $\mathrm{C}_{20} \mathrm{H}_{20} \mathrm{Cl}_{3} \mathrm{CuN}_{5} \mathrm{O}_{4}$ & $\mathrm{C}_{19.5} \mathrm{H}_{21} \mathrm{CuN}_{5} \mathrm{O}_{4.5}$ & $\mathrm{C}_{25} \mathrm{H}_{33} \mathrm{CuN}_{5} \mathrm{O}_{6}$ \\
\hline formula mass & 299.34 & 485.99 & 466.16 & 564.31 & 460.95 & 563.10 \\
\hline crystal system & monoclinic & triclinic & monoclinic & monoclinic & monoclinic & monoclinic \\
\hline space group & $P 2{ }_{1} / \mathrm{c}$ & $P \overline{1}$ & $P 2_{1} / \mathrm{c}$ & $C 2 / c$ & $P 2_{1} / c$ & $C 2 / c$ \\
\hline$A[\AA]$ & $10.358(5)$ & $8.472(6)$ & $8.540(3)$ & 17.814(6) & $8.492(2)$ & 20.217(7) \\
\hline$B[\AA]$ & $16.092(7)$ & $8.791(8)$ & $16.459(6)$ & $8.720(3)$ & $16.417(4)$ & $8.517(3)$ \\
\hline$C[\AA]$ & $9.243(4)$ & $15.212(9)$ & $16.118(5)$ & $18.811(6)$ & $16.134(4)$ & $18.456(9)$ \\
\hline$\alpha\left[^{\circ}\right]$ & 90 & $88.116(9)$ & 90 & 90 & 90 & 90 \\
\hline$\beta\left[^{\circ}\right]$ & $92.219(8)$ & $87.745(9)$ & $97.415(2)$ & $100.237(6)$ & 97.919(3) & $121.319(5)$ \\
\hline$\gamma\left[^{\circ}\right]$ & 90 & $82.924(9)$ & 90 & 90 & 90 & 90 \\
\hline$V\left[\AA^{3}\right]$ & $1539.6(1)$ & $1122.8(3)$ & $2246.4(1)$ & $2875.6(2)$ & $2227.4(9)$ & 2714.1(2) \\
\hline$Z$ & 4 & 2 & 4 & 4 & 2 & 4 \\
\hline$D_{\text {Calcd }}$ & 1.291 & 1.438 & 1.378 & 1.305 & 1.375 & 1.378 \\
\hline$\mu\left[\mathrm{mm}^{-1}\right]$ & 0.090 & 0.873 & 1.248 & 1.220 & 1.017 & 0.852 \\
\hline$F[000]$ & 632 & 502 & 1078 & 1148 & 952 & 1180 \\
\hline$\theta\left[^{\circ}\right]$ & $1.97-27.88$ & $2.42-20.24$ & $2.55-25.67$ & $2.61-26.06$ & $1.78-25.10$ & $2.43-25.10$ \\
\hline reflections collected & 9448 & 3464 & 11338 & 7339 & 11165 & 6663 \\
\hline$R_{\text {(int) }}$ & 0.0254 & 0.0642 & 0.0319 & 0.0547 & 0.0433 & 0.0400 \\
\hline$R_{1}[I>2 \sigma(I)]^{a}$ & 0.0397 & 0.0525 & 0.0633 & 0.0844 & 0.0520 & 0.0483 \\
\hline$w R_{2}$ (all data) & 0.1100 & 0.1262 & 0.2083 & 0.2749 & 0.1629 & 0.1414 \\
\hline
\end{tabular}

$\left.{ }^{a} R_{1}=\sum|| F_{\mathrm{o}}|-| F_{\mathrm{c}} \mid\right) / \sum\left|F_{\mathrm{o}}\right| ; w R_{2}=\left[\sum w\left(F_{\mathrm{o}}^{2}-F_{\mathrm{c}}^{2}\right)^{2} / \sum w\left(F_{\mathrm{o}}^{2}\right)^{2}\right]^{1 / 2}$.

with methanol and water. dpap was obtained as a white powder $(5.8 \mathrm{~g}$, $64 \%$ ). The aqueous solution of dpap was stirred for a half hour and then allowed to evaporate at room temperature. Well-shaped block crystals of $\mathbf{1}$ appeared in several days. Anal. Calcd (\%) for $\mathrm{C}_{15} \mathrm{H}_{17} \mathrm{~N}_{5} \mathrm{O}_{2}$ (299.34): C 60.19, H 5.72, N 23.40; found C 60.36, H 5.83, N 23.32. MS (FAB) $m / z(\%) 264.1$ (dpap). IR $\left(v_{\max } / \mathrm{cm}^{-1}\right) 3301 \mathrm{w}, 3203 \mathrm{w}, 3110 \mathrm{w}$, $1643 \mathrm{~m}, 1610 \mathrm{~s}, 1572 \mathrm{~s}, 1504 \mathrm{~s}, 1443 \mathrm{~s}, 1346 \mathrm{~m}, 1268 \mathrm{w}, 1210 \mathrm{~m}, 1160 \mathrm{w}$, $1000 \mathrm{~m}, 819 \mathrm{w}, 783 \mathrm{~m}, 723 \mathrm{~m}$.

Synthesis of $\left\{\left[\mathrm{Cu}(\text { dpap })(\mathrm{OAc})_{2}\right] \cdot \mathrm{CH}_{3} \mathbf{C N}\right\}_{n}\left(2 \cdot \mathrm{CH}_{3} \mathrm{CN}\right)$. A methanolic solution $(5 \mathrm{~mL})$ of dpap $(0.1 \mathrm{mmol}, 0.026 \mathrm{~g})$ placed at the bottom of a straight glass tube was covered with $\mathrm{CH}_{3} \mathrm{CN}(5 \mathrm{~mL})$, over which a solution of $\mathrm{Cu}(\mathrm{OAc})_{2} \cdot 2 \mathrm{H}_{2} \mathrm{O}(0.2 \mathrm{mmol}, 0.044 \mathrm{~g})$ in methanol $(5 \mathrm{~mL})$ was carefully layered. Over a period of approximately two weeks, the crystal of $\mathbf{2} \cdot \mathbf{C H}_{3} \mathbf{C N}$ was obtained on the wall of the tube. Yield: 0.0221 g (56\%). Anal. Calcd (\%) for $\mathrm{C}_{21} \mathrm{H}_{22} \mathrm{CuN}_{6} \mathrm{O}_{4}(485.99)$ : $\mathrm{C} 51.90, \mathrm{H}$ 4.56, N 17.29; Found C 51.86, H 4.45, N 17.38. IR $\left(v_{\max } / \mathrm{cm}^{-1}\right)$ : $3316 \mathrm{w}$, $3118 \mathrm{w}, 2356 \mathrm{~m}, 2100 \mathrm{~m}, 1577 \mathrm{~s}, 1345 \mathrm{~s}, 1210 \mathrm{~m}, 1027 \mathrm{~m}, 829 \mathrm{w}, 798 \mathrm{w}$.

Synthesis of $\left\{\left[\mathrm{Cu}(\mathrm{dpap})(\mathrm{OAc})_{2}\right] \cdot 0.25 \mathrm{CH}_{2} \mathrm{Cl}_{2}\right\}_{n}\left(\mathbf{2} \cdot \mathbf{0 . 2 5} \mathrm{CH}_{2} \mathrm{Cl}_{2}\right)$, $\left\{\left[\mathrm{Cu}(\text { dpap })(\mathrm{OAc})_{2}\right] \cdot \mathrm{CHCl}_{3}\right\}_{n}\left(2 \cdot \mathrm{CHCl}_{3}\right)$, and $\left\{\left[\mathrm{Cu}(\right.\right.$ dpap $\left.)(\mathrm{OAc})_{2}\right] \cdot$ $\left.0.5 \mathrm{CH}_{3} \mathrm{OH}\right\}_{n}\left(2 \cdot 0.5 \mathrm{CH}_{3} \mathrm{OH}\right)$. Compound $2 \cdot 0.25 \mathrm{CH}_{2} \mathrm{Cl}_{2}, \mathbf{2} \cdot \mathrm{CHCl}_{3}$, and $\mathbf{2} \cdot \mathbf{0 . 5} \mathbf{C H}_{3} \mathbf{O H}$ were prepared as $\mathbf{2} \cdot \mathbf{C H}_{3} \mathbf{C N}$ by using $\mathrm{CH}_{2} \mathrm{Cl}_{2}(5 \mathrm{~mL})$, $\mathrm{CHCl}_{3}(5 \mathrm{~mL})$ and $\mathrm{CH}_{3} \mathrm{OH}(5 \mathrm{~mL})$ instead of $\mathrm{CH}_{3} \mathrm{CN}$, respectively. Yield for $\mathbf{2 \cdot 0 . 2 5} \mathbf{C H}_{2} \mathbf{C l}_{2}$ : $0.0326 \mathrm{~g}(62 \%)$. Anal. Calcd $(\%)$ for $\mathrm{C}_{19.25} \mathrm{H}_{19.50} \mathrm{Cl}_{0.5} \mathrm{CuN}_{5} \mathrm{O}_{4}$ (466.16): $\mathrm{C} 49.60, \mathrm{H} 4.22, \mathrm{~N} 15.02$; found $\mathrm{C}$ 49.70, H 4.20, N 15.41. IR $\left(v_{\max } / \mathrm{cm}^{-1}\right): 3106 \mathrm{w}, 1577 \mathrm{~s}, 1393 \mathrm{~s}, 1211 \mathrm{~s}$, $1028 \mathrm{~m}, 732 \mathrm{~m}, 677 \mathrm{~m}$.

Yield for $\mathbf{2} \cdot \mathbf{C H C l}_{3}$ : $0.0258 \mathrm{~g}(52 \%)$. Anal. Calcd (\%) for $\mathrm{C}_{20} \mathrm{H}_{20^{-}}$ $\mathrm{Cl}_{3} \mathrm{CuN}_{5} \mathrm{O}_{4}$ (564.31): $\mathrm{C} 42.51, \mathrm{H} 3.57, \mathrm{~N} 12.41$; found: $\mathrm{C} 42.46, \mathrm{H}$ 3.60, N 12.49. IR $\left(v_{\max } / \mathrm{cm}^{-1}\right): 3172 \mathrm{w}, 1629 \mathrm{~m}, 1583 \mathrm{~s}, 1367 \mathrm{~s}, 1210 \mathrm{~s}$, $1018 \mathrm{~m}, 754 \mathrm{~m}, 674 \mathrm{~m}$.

Yield for $\mathbf{2 \cdot 0 . 5} \mathbf{C H}_{3} \mathbf{O H}$ : $0.0421 \mathrm{~g}(64 \%)$. Anal. Calcd (\%) for $\mathrm{C}_{19.5} \mathrm{H}_{21} \mathrm{CuN}_{5} \mathrm{O}_{4.5}$ (460.95): C 50.81, H 4.59, N 15.19; Found C 50.78, $\mathrm{H} 4.50, \mathrm{~N} 15.28$. IR $\left(v_{\max } / \mathrm{cm}^{-1}\right): 3300 \mathrm{~m}, 1584 \mathrm{~s}, 1339 \mathrm{~s}, 1253 \mathrm{~m}, 1212 \mathrm{~m}$, $1059 \mathrm{~m}, 836 \mathrm{~m}, 742 \mathrm{w}$.

Synthesis of $\left\{\left[\mathrm{Cu}(\text { dpap })(\mathrm{maa})_{2}\right] \cdot \mathbf{2} \mathrm{CH}_{3} \mathrm{OH}\right\}_{n}\left(\mathbf{3} \cdot \mathbf{2} \mathrm{CH}_{3} \mathrm{OH}\right)$. A methanol $(10 \mathrm{~mL})$ solution of $\mathrm{Cu}(\mathrm{maa})_{2}(0.2 \mathrm{mmol}, 0.047 \mathrm{~g})$ was placed on the top of solution of dpap $(0.1 \mathrm{mmol}, 0.026 \mathrm{~g})$ in methanol $(10 \mathrm{~mL})$. The mixture solution evaporates at room temperature. Well-shaped green block crystals of $\mathbf{3} \cdot \mathbf{2} \mathbf{C H}_{\mathbf{3}} \mathbf{O H}$ appeared in several days. The crystalline product was filtered, washed with ethanol, and dried in air. Yield: $0.0468 \mathrm{~g}(53 \%)$. Anal. Calcd (\%) for $\mathrm{C}_{25} \mathrm{H}_{33} \mathrm{CuN}_{5} \mathrm{O}_{6}(563.10)$ : C 53.32, H 5.91, N 12.44; Found C 53.40, H 5.84, N 12.41. IR ( $v_{\max } /$ $\mathrm{cm}^{-1}$ ): 3302m, 1578s, 1506m, 1368s, 1235s, 1060m, 856w.

X-ray Crystallography. Diffraction experiments for $\mathbf{1 , 2} \cdot \mathbf{C H}_{3} \mathbf{C N}$,

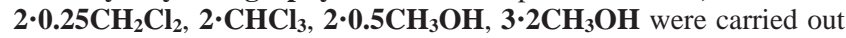
with Mo- $K_{\alpha}$ radiation using a BRUKER SMART APEXCCD diffractometer at 293(2) K. A summary of the crystallography data and structure refinement is given in Table 1 . The structures were solved by direct methods and refined with the full-matrix least-squares technique on $F^{2}$ using the SHELXS-97 ${ }^{12}$ and SHELXL-9 $97^{13}$ programs.
All non-hydrogen atoms were refined anisotropically. The hydrogen atoms attached to ligands were generated geometrically; the solvent hydrogen atoms were located from difference Fourier maps and fixed isotropic displacement parameters. In compound $\mathbf{2} \cdot \mathbf{C H C l}_{3}$, the chloroform molecules present the disordered in half-occupied position. X-ray crystallographic data in CIF format for the structures reported in this paper have been deposited with the Cambridge Crystallographic Data Centre. CCDC No. 294853 for $\mathbf{1}, 294848$ for $\mathbf{2} \cdot \mathbf{C H}_{\mathbf{3}} \mathbf{C N}, 294849$ for

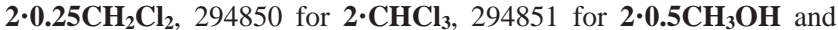
294852 for $\mathbf{3} \cdot \mathbf{2} \mathbf{C H}_{3} \mathbf{O H}$. Copies of this information may be obtained free of charge on application to CCDC, 12 Union Road, Cambridge CB2 1EZ, UK (fax: +44-1223-336-033; e-mail: deposit@ccdc.cam.ac.uk or http://www.ccdc.cam.ac.uk).

\section{Results and Discussion}

Synthesis. The methanolic solvent of dpap was placed at the bottom of glass vial and it was covered with different buffering solvents. A solvent of $\mathrm{Cu}(\mathrm{OAc})_{2}$ in methanol was layered on the buffering solvent. Compounds $\mathbf{2} \cdot \mathbf{C H}_{\mathbf{3}} \mathbf{C N}, \mathbf{2 \cdot 0 . 2 5} \mathbf{C H}_{\mathbf{2}} \mathbf{C l}_{\mathbf{2}}$, $\mathbf{2} \cdot \mathbf{C H C l}_{3}$, and $\mathbf{2} \cdot \mathbf{0 . 5} \mathbf{C H}_{3} \mathrm{OH}$ were obtained by using different solvents as the buffering solvent $\left(\mathrm{CH}_{3} \mathrm{CN}\right.$ for $\mathbf{2} \cdot \mathbf{C H}_{\mathbf{3}} \mathbf{C N}, \mathrm{CH}_{2} \mathrm{Cl}_{2}$ for $\mathbf{2} \cdot \mathbf{0 . 2 5} \mathbf{C H}_{2} \mathbf{C l}_{2}, \mathrm{CHCl}_{3}$ for $\mathbf{2} \cdot \mathbf{C H C l}_{3}$, and $\mathrm{CH}_{3} \mathrm{OH}$ for $\left.\mathbf{2} \cdot \mathbf{0 . 5} \mathbf{C H}_{3} \mathbf{O H}\right)$ with the $\mathrm{Cu}(\mathrm{OAc})_{2} /$ dpap stoichiometry of 2:1. When the diffusion solvent was DMF, DMSO, or EtOH, only methanol molecules were found in the channels (Scheme 1). The main function of the buffering solvent is to slow the rate of the reaction and hence crystallization. However, we also observed more profound effects of methanol and different solvents. This will be discussed in the latter part of this paper. Compound $\mathbf{3} \cdot \mathbf{2} \mathbf{C H}_{3} \mathbf{O H}$ was obtained from methanolic solutions of $\mathrm{Cu}(\mathrm{maa})_{2}$ and dpap (stoichiometry of $2: 1$ ).

Description of the Structures. dpap $2 \mathrm{H}_{2} \mathrm{O}$ (1). The singlecrystal X-ray structural analysis shows that $\mathbf{1}$ crystallizes in the monoclinic $P 2_{1} / c$ space group. The dihedral angle between the polar pyridyl plane is $43.83^{\circ}$, and the center-to-center distance is $5.987 \AA$ (Figure 1a). As shown in Figure 1b, dpap is held together by two water molecules on each side via three different hydrogen-bonding interactions $\left(\mathrm{N}_{\text {amino }} \cdots \mathrm{O}, \mathrm{N}_{\text {pyridyl }} \cdots \mathrm{O}, \mathrm{O} \cdots \mathrm{O}\right)$ with bond lengths of 2.936(2), 2.783(2), and 2.806(2) $\AA$, respectively, and give rise to a three-dimensional (3D) binodal $(3,4)$ connected net. In a simplified view, it is composed of two alternating four-connecting $(\mathrm{O})$ and triangular three-connecting (dpap) nodes. ${ }^{14}$

$\left\{\left[\mathbf{C u}(\text { dpap })(\mathrm{OAc})_{2}\right] \cdot \mathbf{C H}_{3} \mathbf{C N}\right\}_{n} \quad\left(\mathbf{2} \cdot \mathbf{C H}_{3} \mathbf{C N}\right)$. Complex $\mathbf{2} \cdot$ $\mathbf{C H}_{3} \mathbf{C N}$ crystallizes in the triclinic system, $P \overline{1}$ space group, and 
Scheme 1. Summary of the Chemistry of dpap

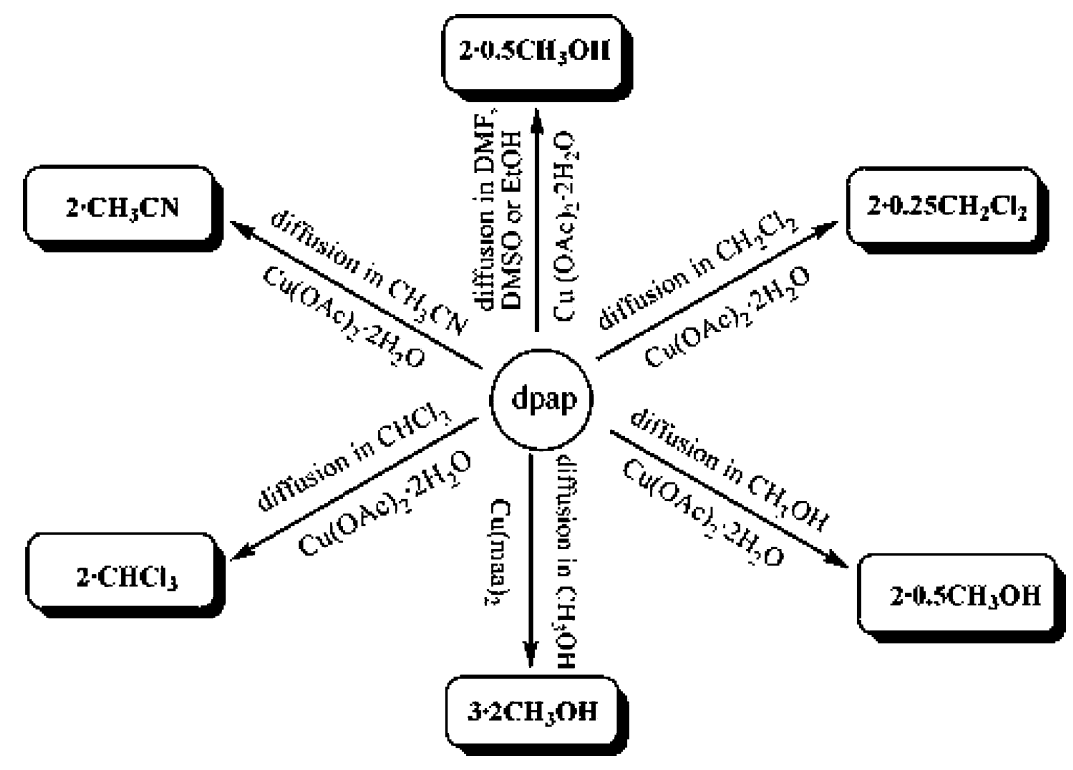

the coordination environment around copper(II) ion is shown in Figure 2a along with the atom numbering scheme. The asymmetric unit of $\mathbf{2} \cdot \mathbf{C H}_{3} \mathbf{C N}$ contains two distinct $\mathrm{Cu}$ centers
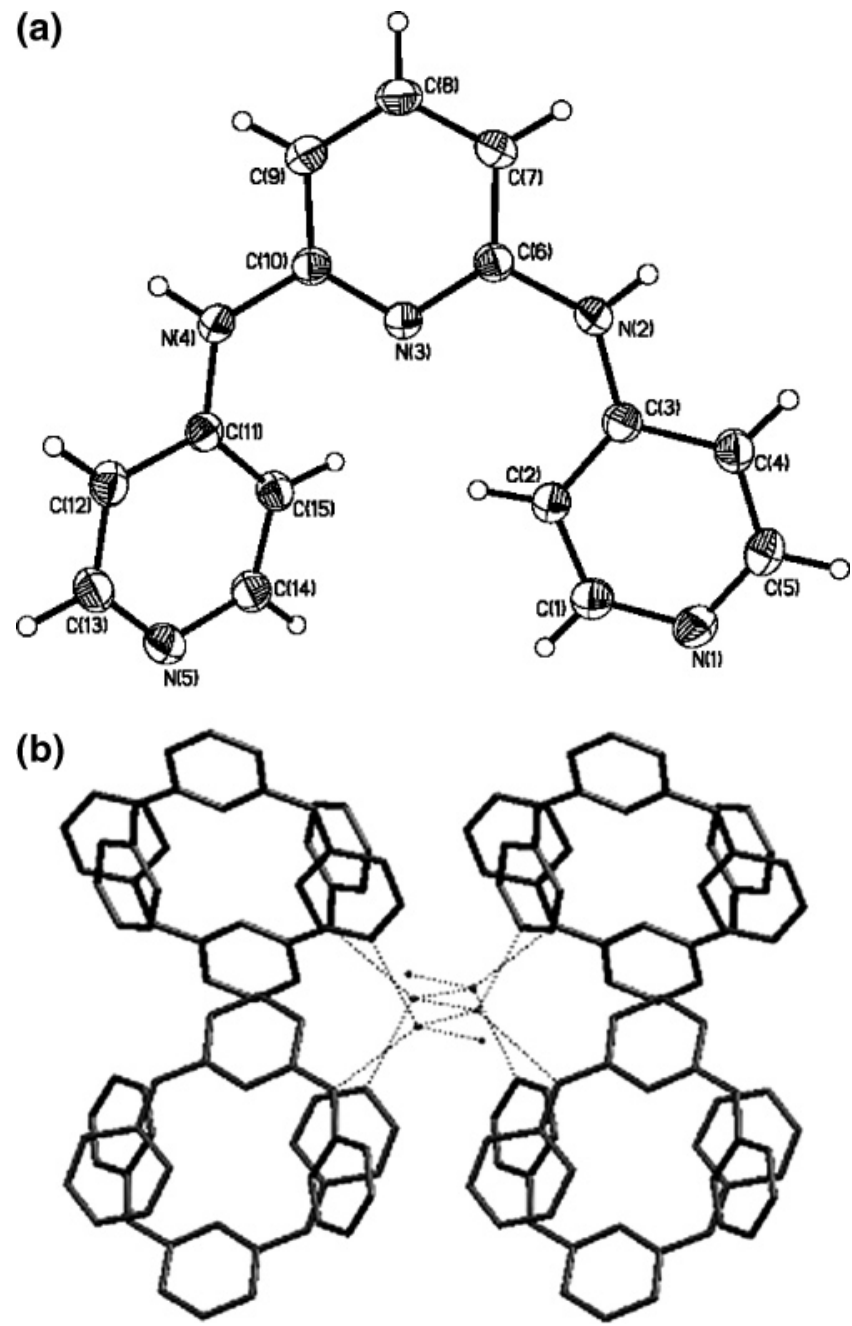

Figure 1. (a) ORTEP view of 1 with atomic numbering scheme. The atoms are represented by $30 \%$ probable thermal ellipsoids. Two water molecules are omitted for clarity; (b) 3D $(3,4)$ network of $\mathbf{1}$ connected by water molecules (hydrogen atoms are omitted for clarity).
(Table 2). $\mathrm{Cu}(1)$ atoms are coordinated to two $\mathrm{N}$ atoms of a pyridine unit from different dpap molecules $(\mathrm{Cu}(1)-\mathrm{N}(1) \# 1$, $2.010(6) \AA)$, and two additional positions are occupied by $\mathrm{O}$ atoms from carboxylate groups $(\mathrm{Cu}(1)-\mathrm{O}(1) \# 1,1.951(6) \AA)$ (symmetry codes: \#1: $-x,-y+1,-z+1$ ) Therefore, the local coordination geometry around $\mathrm{Cu}(1)$ can be regarded as square-planar with an $\mathrm{N}_{2} \mathrm{O}_{2}$ donor set. $\mathrm{Cu}(2)$ has a similar square-planar coordination geometry also with a $\mathrm{N}_{2} \mathrm{O}_{2}$ binding set but with a short distance of $\mathrm{Cu}(2)-\mathrm{N}(5) \# 2$ (1.957(6) $\AA$ ) and a longer distance of $\mathrm{Cu}(2)-\mathrm{O}(3) \# 2$ (1.992(6) $\AA$ ) (symmetry codes: \#2: $-x,-y+2,-z)$. dpap links copper(II) ions to form an infinite zigzag chain along the [01] direction. The dihedral angle between the polar pyridyl planes of dpap is $5.71^{\circ}$. Neighboring copper centers in the chain are separated by the ligand at a distance of $8.66 \AA$. The adjacent chains are connected via two strong hydrogen bonds $\left(\mathrm{N}_{\text {amino }} \cdots \mathrm{O}_{\text {carboxylic }} 2.836(10) \AA\right.$, $\mathrm{N}_{\text {amino }} \cdots \mathrm{O}_{\text {carboxylic }} 2.814(10) \AA$ ) and form $\left[\mathrm{Cu}(\text { dpap })(\mathrm{OAc})_{2}\right]_{n}$ as wavelike layers (Figure 2b). It is worth mentioning that this kind of hydrogen-bonding network, which is characteristic of those polymers, responds flexibly and affects the structure according to the guest molecules. The layers are perpendicular to [011] and can be simplified as binodal $(3,4)$ nets with the Schläfli symbol $\left\{4 \cdot 6^{2}\right\} 2\left\{4^{2} \cdot 6^{2}\right\}$. In the packing arrangement of $\mathbf{2} \cdot \mathbf{C H}_{\mathbf{3}} \mathbf{C N}$, the layers are parallel and stacked without interpenetrating to generate open channels. The channels in $\mathbf{2} \cdot \mathbf{C H}_{\mathbf{3}} \mathbf{C N}$ possess approximate dimensions of $15.21 \times 8.79 \AA$ (atom-toatom), which are occupied by $\mathrm{CH}_{3} \mathrm{CN}$ molecules arranged in an $\mathrm{ABAB}$ fashion in each row (Figure 2c). Calculations using PLATON ${ }^{15}$ revealed that the open channels constitute about $18.4 \%$ (206.7 $\AA^{3}$ out of $1122.8 \AA^{3}$ ) of the crystal volume. Since the shortest distance from the host atom (carboxylic oxygen atom) to the carbon atom (methyl) is $3.375 \AA$, the guest $\mathrm{CH}_{3} \mathrm{CN}$ molecules are stabilized by hydrogen-bonding interactions.

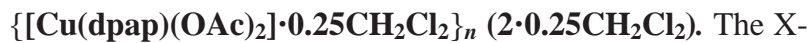
ray crystallographic study shows that $\mathbf{2} \cdot \mathbf{0 . 2 5} \mathbf{C H}_{\mathbf{2}} \mathbf{C l}_{\mathbf{2}}$ crystallizes in the monoclinic system, space group $P 2_{1} / c$, and the copper(II) ion lies in a square-planar configuration with a $\mathrm{N}_{2} \mathrm{O}_{2}$ donor set. Compound $\mathbf{2} \cdot \mathbf{0 . 2 5} \mathbf{C H}_{\mathbf{2}} \mathbf{C l}_{\mathbf{2}}$ is a helical chain consisting of $\mathrm{Cu}$ (dpap)(OAc) $)_{2}$ units. As shown in Figure 3a, each ligand links two copper cations along the $b$-axis to form a right-handed helical chain that is generated by a $2_{1}$ axis with a pitch of 16.459 $\AA$, containing two copper(II) ions per turn. Then, as mentioned 
(a)

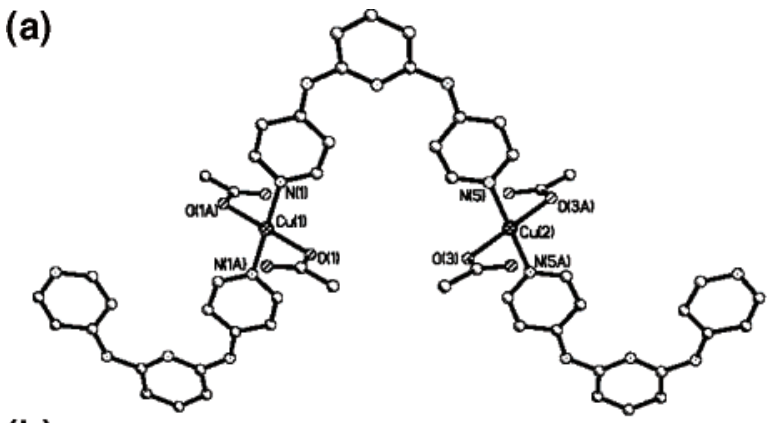

(b)

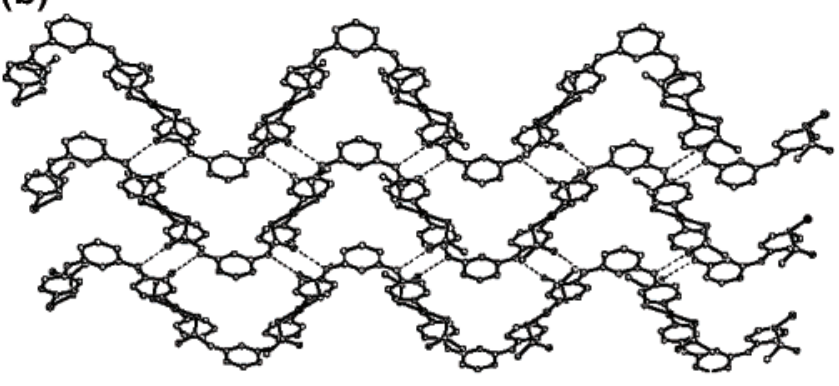

(c)

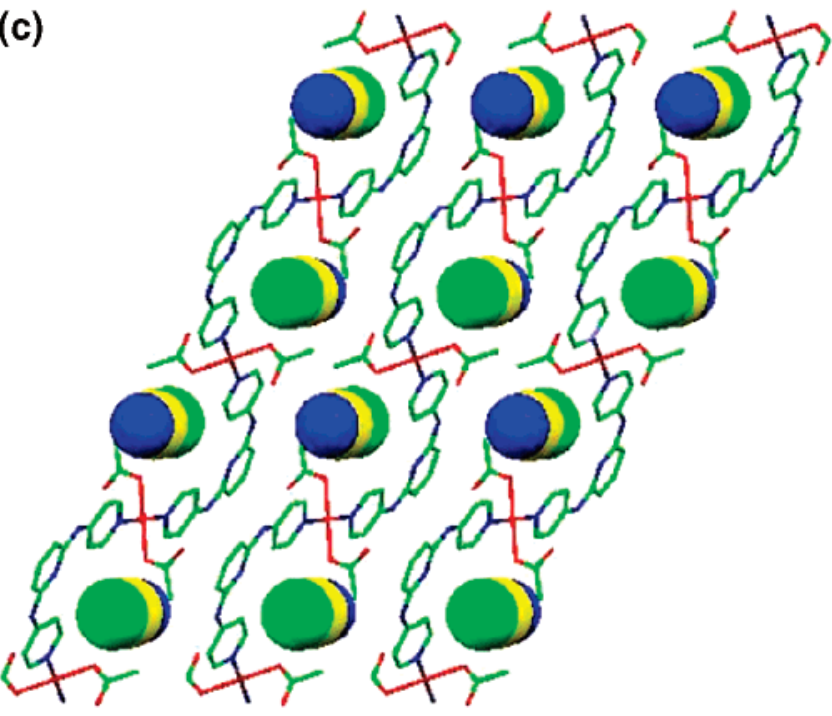

Figure 2. (a) View of the copper coordination environment of $\mathbf{2} \cdot \mathbf{C H}_{3} \mathbf{C N}$ with atom labeling scheme (hydrogen atoms and $\mathrm{CH}_{3} \mathrm{CN}$ are omitted for clarity); (b) view of the 2D hydrogen-bonding layer structure of $\mathbf{2} \cdot \mathbf{C H}_{3} \mathbf{C N}$ (hydrogen atoms and solvent molecules are omitted for clarity); (c) perspective views of $\mathbf{2} \cdot \mathbf{C H}_{\mathbf{3}} \mathbf{C N}$ highlighting the guest molecules in the cavities. Color codes for $\mathrm{C}, \mathrm{N}$, and $\mathrm{O}$ atoms are green (yellow in cyano), blue, and red.

above, hydrogen bonding (2.886(1) $\mathrm{A}, 2.868(1) \AA$ ) (Figure 3b) through an amino group to secondary carboxylate oxygen atoms located in the neighboring chains generate 2D layers, which are of the same topological type as in $\mathbf{2} \cdot \mathbf{C H}_{\mathbf{3}} \mathbf{C N}$ and stacks perpendicular to the $a b$ plane. The layers are further linked to each other by $\mathrm{C}-\mathrm{H} \cdots \mathrm{O}$ (carboxyl) hydrogen-bonding interactions to generate a neutral 3D framework with open channels (ca. $14.34 \times 16.27 \AA$ ). Calculations from the X-ray structural parameters show that solvent-accessible void space in the channels is approximately $19.1 \% .^{15}$

$\left\{\left[\mathrm{Cu}(\mathrm{dpap})(\mathbf{\mathrm { OAc }})_{2}\right] \cdot \mathbf{C H C l}_{3}\right\}_{n}\left(\mathbf{2} \cdot \mathbf{C H C l}_{3}\right)$. Interestingly, the structure of $\mathbf{2} \cdot \mathbf{C H C l}_{\mathbf{3}}$ is another example of solvent-induced architecture. In the complex, dpap is employed as a bridging ligand for the construction of a one-dimensional (1D) chain along the crystallographic $c$-axis (Figure 4a), which has alternating helical parts (alternating right and left turns of the strand looking down the "growth axis"). However, the chain is not a helical structure, because the strand contains centers of inversion and does not have defined chirality, so we call it a meso-helix chain, which is found by us ${ }^{16}$ and others. ${ }^{17}$ The combination of helixes to form a chiral or meso structure is interesting in chiral coordination polymers. Neighboring copper centers are separated by the ligand at a distance of about $9.405 \AA$. Again, the same $\left\{4 \cdot 6^{2}\right\} 2\left\{4^{2} \cdot 6^{2}\right\}$ layer is formed, which is perpendicular to the $b c$ plane. The common $\mathrm{N}-\mathrm{H} \cdots \mathrm{O}$ hydrogen-bonding distance is about 2.839(2) $\AA$. Parallel chains further stack to form 3D structures via hydrogen-bonding interactions with cavity dimensions of $14.72 \times 12.53 \AA$. These open channels constitute about $41.7 \%\left(2875.6 \AA^{3}\right)$ of the crystal volume (PLATON ${ }^{15}$ ) and are occupied by the $\mathrm{CHCl}_{3}$ solvent molecules. The other intriguing structure feature is that in the packing arrangement of $\mathbf{2} \cdot \mathbf{C H C l}_{\mathbf{3}}$, the ordered guest $\mathrm{CHCl}_{3}$ molecules line up in these $1 \mathrm{D}$ channels and are aggregated in pairs into clusters (Figure 4b), with the shortest intermolecular $\mathrm{Cl} \cdots \mathrm{Cl}$ distance of $3.333 \AA$. Such ordered guests provide an extraordinary model for arrangement of solvent molecules. ${ }^{18}$

$\left\{\left[\mathrm{Cu}(\mathrm{dpap})(\mathrm{OAc})_{2}\right] \cdot 0.5 \mathrm{CH}_{3} \mathrm{OH}\right\}_{n}\left(\mathbf{2} \cdot \mathbf{0 . 5} \mathrm{CH}_{3} \mathrm{OH}\right)$. The crys-

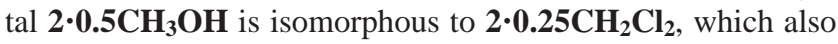
gives a helix superstructure generated by a $2_{1}$ axis with a pitch of 16.417(4) $\AA$ (Figure 5). The detailed geometric data of $\mathbf{2}$. $\mathbf{0 . 5} \mathrm{CH}_{3} \mathrm{OH}(\mathrm{Cu}-\mathrm{N} 2.008(3)-2.014(3) \AA ; \mathrm{Cu}-\mathrm{O}$ 1.943(3)1.960(3) $\AA$ ) resemble those of $\mathbf{2 \cdot 0 . 2 5} \mathbf{C H}_{\mathbf{2}} \mathbf{C l} \mathbf{l}_{\mathbf{2}}$ with only minor deviations (Table 2). Interestingly, the framework undergoes a slightly shrinkage so that the channel cavities suit $\mathrm{CH}_{3} \mathrm{OH}$ molecules very well, resulting in an appreciable difference in channel size for $\mathrm{CH}_{2} \mathrm{Cl}_{2}$. The size of the rectangular channel in the presence of $\mathrm{CH}_{2} \mathrm{Cl}_{2}$ is $14.34 \times 16.27 \AA$, whereas in the presence of $\mathrm{CH}_{3} \mathrm{OH}$ the size changes to $14.33 \times 16.23 \AA$ without a serious change in shape. The unit cell volume of $\mathbf{2} \cdot \mathbf{0 . 5} \mathrm{CH}_{3} \mathrm{OH}$ is decreased. Moreover, $\mathbf{2} \cdot \mathbf{0 . 5} \mathbf{C H}_{\mathbf{3}} \mathbf{O H}$ still possesses channels having $18.2 \%$ volume of unit cell, ${ }^{15}$ which is also slightly

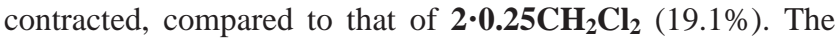
nearest distance between $\mathrm{Cu}$ atoms of the adjacent layers in

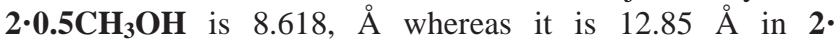
$\mathbf{0 . 2 5 C H}_{2} \mathbf{C l}_{2}$. There still exist hydrogen-bonding interactions between the amino group and carboxylate oxygen atoms with a distance of 2.844(2) and 2.853(2) $\AA$, which is shorter than that of $\mathbf{2 \cdot 0 . 2 5} \mathbf{C H}_{\mathbf{2}} \mathbf{C l}_{\mathbf{2}}$. This is a representative of a flexible framework that affords responsive fitting capability to the size of guest molecules.

$\left\{\left[\mathrm{Cu}(\text { dpap})(\mathrm{maa})_{2}\right] \cdot \mathbf{2} \mathrm{CH}_{3} \mathrm{OH}\right\}_{n}\left(\mathbf{3} \cdot \mathbf{2} \mathrm{CH}_{3} \mathrm{OH}\right)$. To investigate the influence of the anion on the formation of the polymer structure, the $\mathrm{OAc}^{-}$anion was replaced by an maa ${ }^{-}$anion. X-ray structural analysis has revealed that $\mathbf{3} \cdot \mathbf{2} \mathbf{C H}_{3} \mathbf{O H}$ consists of $1 \mathrm{D}$ meso-helix chains based on the $\mathrm{Cu}(\mathrm{maa})_{2}$ node. Again, the same $\left\{4 \cdot 6^{2}\right\} 2\left\{4^{2} \cdot 6^{2}\right\}$ layers are formed, which are perpendicular to the $a c$ plane. Parallel chains further stack to form 3D structures (Figure 6). Apart from small differences in detailed geometric data, the two copper ions of $\mathbf{2} \cdot \mathbf{0 . 5} \mathbf{C H}_{3} \mathbf{O H}$ and $\mathbf{3} \cdot \mathbf{2} \mathrm{CH}_{3} \mathrm{OH}$ are located at equivalent sites. In the unit, each copper atom has a slightly distorted square-planar coordination environment, with two atoms from two maa groups, and two pyridyl nitrogen atoms. The $\mathrm{Cu}$-to- $\mathrm{Cu}$ distance is $9.505 \AA$, which is longer than that of $\mathbf{2} \cdot \mathbf{0 . 5} \mathbf{C H}_{3} \mathbf{O H}(8.349 \AA)$. In the packing arrangement of $\mathbf{3} \cdot \mathbf{2} \mathbf{C H}_{3} \mathrm{OH}$, similar to that of $\mathbf{2} \cdot \mathbf{C H C l}_{3}$, the pairs of $\mathrm{CH}_{3} \mathrm{OH}$ molecules are encapsulated in the 1D channel, which has a larger dimension $(20.30 \times 16.29 \AA)$ than that of $\mathbf{2} \cdot \mathbf{0 . 5} \mathbf{C H}_{\mathbf{3}} \mathbf{O H}$. These channels constitute $22.3 \%$ of the crystal volume ${ }^{15}$ and are larger than those found in $\mathbf{2 \cdot 0 . 5} \mathbf{C H}_{3} \mathbf{O H}(18.2 \%)$. Yaghi and coworkers have also shown that fragments in combination with 


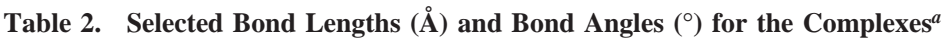

\begin{tabular}{|c|c|c|c|c|c|}
\hline \multicolumn{6}{|c|}{1} \\
\hline $\mathrm{N}(1)-\mathrm{C}(1)$ & $1.332(2)$ & $\mathrm{N}(5)-\mathrm{C}(14)$ & $1.336(6)$ & $\mathrm{C}(1)-\mathrm{N}(1)-\mathrm{C}(5)$ & $115.2(6)$ \\
\hline $\mathrm{N}(1)-\mathrm{C}(5)$ & $1.341(5)$ & $\mathrm{N}(5)-\mathrm{C}(13)$ & $1.341(6)$ & $C(14)-N(5)-C(13)$ & $115.6(8)$ \\
\hline \multicolumn{6}{|c|}{$2 \cdot \mathrm{CH}_{3} \mathrm{CN}$} \\
\hline $\mathrm{Cu}(1)-\mathrm{O}(1 \mathrm{~A}) \# 1$ & $1.951(6)$ & $\mathrm{Cu}(2)-\mathrm{N}(5 \mathrm{~A}) \# 2$ & $1.992(6)$ & $\mathrm{O}(1)-\mathrm{Cu}(1)-\mathrm{N}(1)$ & $89.2(3)$ \\
\hline $\mathrm{Cu}(1)-\mathrm{O}(1)$ & $1.951(6)$ & $\mathrm{Cu}(2)-\mathrm{N}(5)$ & $1.992(6)$ & $\mathrm{N}(1 \mathrm{~A}) \# 1-\mathrm{Cu}(1)-\mathrm{N}(1)$ & 180.0 \\
\hline $\mathrm{Cu}(1)-\mathrm{N}(1 \mathrm{~A}) \# 1$ & $2.010(6)$ & $\mathrm{O}(1 \mathrm{~A}) \# 1-\mathrm{Cu}(1)-\mathrm{O}(1)$ & $179.99(1)$ & $\mathrm{O}(3)-\mathrm{Cu}(2)-\mathrm{O}(3 \mathrm{~A}) \# 2$ & 179.99(1) \\
\hline $\mathrm{Cu}(1)-\mathrm{N}(1)$ & $2.010(6)$ & $\mathrm{O}(1 \mathrm{~A}) \# 1-\mathrm{Cu}(1)-\mathrm{N}(1 \mathrm{~A}) \# 1$ & $89.2(3)$ & $\mathrm{O}(3)-\mathrm{Cu}(2)-\mathrm{N}(5 \mathrm{~A}) \# 2$ & $91.0(3)$ \\
\hline $\mathrm{Cu}(2)-\mathrm{O}(3)$ & $1.957(6)$ & $\mathrm{O}(1)-\mathrm{Cu}(1)-\mathrm{N}(1 \mathrm{~A}) \# 1$ & $90.8(3)$ & $\mathrm{O}(3 \mathrm{~A}) \# 2-\mathrm{Cu}(2)-\mathrm{N}(5 \mathrm{~A}) \# 2$ & $89.0(3)$ \\
\hline $\mathrm{Cu}(2)-\mathrm{O}(3 \mathrm{~A}) \# 2$ & $1.957(6)$ & $\mathrm{O}(1 \mathrm{~A}) \# 1-\mathrm{Cu}(1)-\mathrm{N}(1)$ & $90.8(3)$ & $\mathrm{N}(5 \mathrm{~A}) \# 2-\mathrm{Cu}(2)-\mathrm{N}(5)$ & 180.0 \\
\hline \multicolumn{6}{|c|}{$2 \cdot 0.25 \mathrm{CH}_{2} \mathrm{Cl}_{2}$} \\
\hline $\mathrm{Cu}(1)-\mathrm{O}(3)$ & $1.936(3)$ & $\mathrm{O}(3)-\mathrm{Cu}(1)-\mathrm{O}(1)$ & $178.35(2)$ & $\mathrm{N}(1)-\mathrm{Cu}(1)-\mathrm{N}(5) \# 1$ & $178.48(1)$ \\
\hline $\mathrm{Cu}(1)-\mathrm{O}(1)$ & $1.954(2)$ & $\mathrm{O}(3)-\mathrm{Cu}(1)-\mathrm{N}(1)$ & $89.20(1)$ & & \\
\hline $\mathrm{Cu}(1)-\mathrm{N}(1)$ & $2.018(3)$ & $\mathrm{O}(1)-\mathrm{Cu}(1)-\mathrm{N}(1)$ & $90.75(1)$ & & \\
\hline $\mathrm{Cu}(1)-\mathrm{N}(5) \# 1$ & $2.018(3)$ & $\mathrm{O}(3)-\mathrm{Cu}(1)-\mathrm{N}(5) \# 1$ & $89.28(1)$ & & \\
\hline $\mathrm{N}(5)-\mathrm{Cu}(1) \# 2$ & $2.017(3)$ & $\mathrm{O}(1)-\mathrm{Cu}(1)-\mathrm{N}(5) \# 1$ & $90.77(1)$ & & \\
\hline \multicolumn{6}{|c|}{$2 \cdot \mathrm{CHCl}_{3}$} \\
\hline $\mathrm{Cu}(1)-\mathrm{O}(1) \# 1$ & $1.960(5)$ & $\mathrm{O}(1) \# 1-\mathrm{Cu}(1)-\mathrm{O}(1)$ & $180.0(4)$ & $\mathrm{O}(1)-\mathrm{Cu}(1)-\mathrm{N}(1)$ & $90.05(2)$ \\
\hline $\mathrm{Cu}(1)-\mathrm{O}(1)$ & $1.960(5)$ & $\mathrm{O}(1) \# 1-\mathrm{Cu}(1)-\mathrm{N}(1) \# 1$ & $89.9(2)$ & $\mathrm{N}(1)-\mathrm{Cu}(1)-\mathrm{N}(1)$ & $180.0(0)$ \\
\hline $\mathrm{Cu}(1)-\mathrm{N}(1) \# 1$ & $2.016(4)$ & $\mathrm{O}(1)-\mathrm{Cu}(1)-\mathrm{N}(1) \# 1$ & $89.95(2)$ & & \\
\hline $\mathrm{Cu}(1)-\mathrm{N}(1)$ & $2.016(4)$ & $\mathrm{O}(1) \# 1-\mathrm{Cu}(1)-\mathrm{N}(1)$ & $90.05(2)$ & & \\
\hline \multicolumn{6}{|c|}{$2 \cdot 0.5 \mathrm{CH}_{3} \mathrm{OH}$} \\
\hline $\mathrm{Cu}(1)-\mathrm{O}(3)$ & $1.945(3)$ & $\mathrm{O}(3)-\mathrm{Cu}(1)-\mathrm{O}(1)$ & $178.48(1)$ & $\mathrm{O}(1)-\mathrm{Cu}(1)-\mathrm{N}(5) \# 1$ & $90.69(1)$ \\
\hline $\mathrm{Cu}(1)-\mathrm{O}(1)$ & $1.960(3)$ & $\mathrm{O}(3)-\mathrm{Cu}(1)-\mathrm{N}(1)$ & 89.42(1) & $\mathrm{N}(1)-\mathrm{Cu}(1)-\mathrm{N}(5)$ & 178.42(1) \\
\hline $\mathrm{Cu}(1)-\mathrm{N}(1)$ & $2.010(3)$ & $\mathrm{O}(1)-\mathrm{Cu}(1)-\mathrm{N}(1)$ & $90.87(1)$ & & \\
\hline $\mathrm{Cu}(1)-\mathrm{N}(5) \# 1$ & $2.023(3)$ & $\mathrm{O}(3)-\mathrm{Cu}(1)-\mathrm{N}(5) \# 1$ & $89.03(1)$ & & \\
\hline \multicolumn{6}{|c|}{$3 \cdot 2 \mathrm{CH}_{3} \mathrm{OH}$} \\
\hline $\mathrm{Cu}(1)-\mathrm{O}(1)$ & $1.960(3)$ & $\mathrm{O}(1)-\mathrm{Cu}(1)-\mathrm{O}(1) \# 1$ & $180.00(1)$ & $\mathrm{O}(1) \# 1-\mathrm{Cu}(1)-\mathrm{N}(1)$ & $90.18(1)$ \\
\hline $\mathrm{Cu}(1)-\mathrm{O}(1) \# 1$ & $1.960(3)$ & $\mathrm{O}(1)-\mathrm{Cu}(1)-\mathrm{N}(1) \# 1$ & $90.18(1)$ & $\mathrm{N}(1) \# 1-\mathrm{Cu}(1)-\mathrm{N}(1)$ & 179.99(1) \\
\hline $\mathrm{Cu}(1)-\mathrm{N}(1) \# 1$ & $2.016(3)$ & $\mathrm{O}(1) \# 1-\mathrm{Cu}(1)-\mathrm{N}(1) \# 1$ & $89.82(1)$ & & \\
\hline $\mathrm{Cu}(1)-\mathrm{N}(1)$ & $2.016(3)$ & $\mathrm{O}(1)-\mathrm{Cu}(1)-\mathrm{N}(1)$ & $89.77(11)$ & & \\
\hline
\end{tabular}

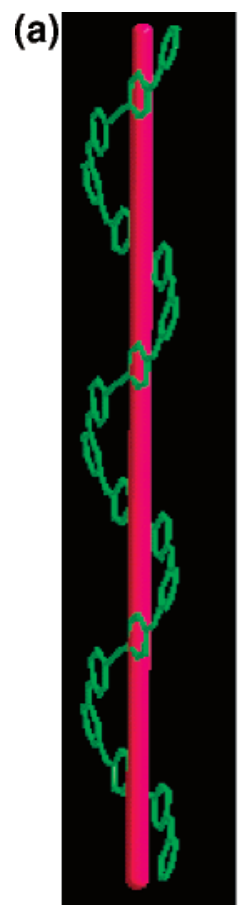

(b)

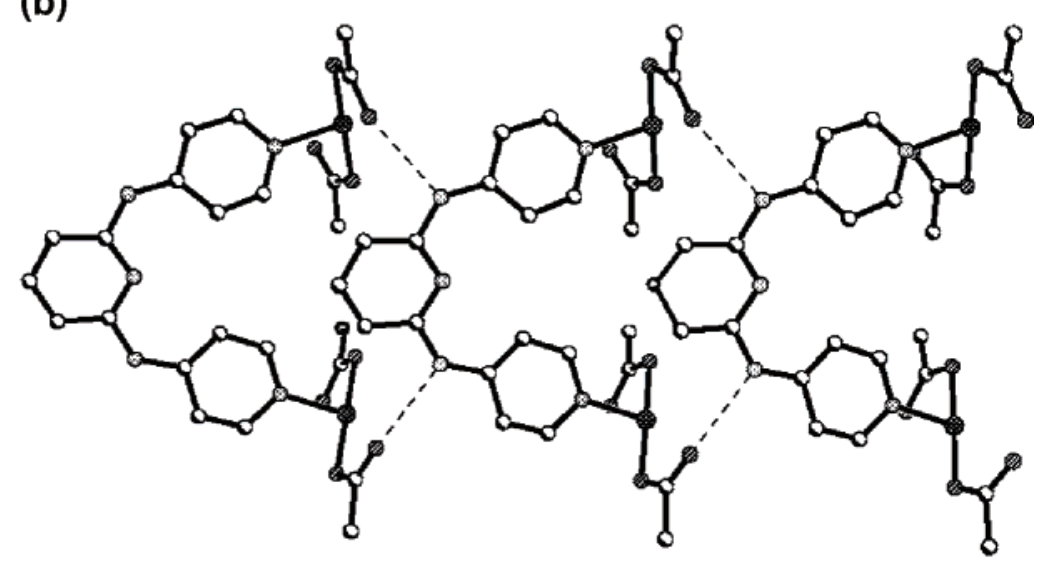

Figure 3. (a) View of a right-handed $2_{1}$ helix of complex $\mathbf{2 \cdot \mathbf { 0 . 2 5 }} \mathbf{C H}_{\mathbf{2}} \mathbf{C l}_{\mathbf{2}}$ along the crystallographic $b$-axis, shown as a thick red bar (only dpap and $\mathrm{Cu}$ atoms are shown for clarity), emphasizing the right-handed (red) helix chains; (b) the hydrogen bonds through amino groups to carboxylate oxygen atoms (hydrogen atoms are omitted for clarity).

long spacer ligands, which can increase the host channel width, reduce the degree of interpenetration and hence bring about guest inclusion in the host. ${ }^{19}$
Selective Guest Inclusions. Selective guest ability of these relative polymers also have been examined. When the diffusion solvent was changed to DMF, the sorption was selective, no 
(a)

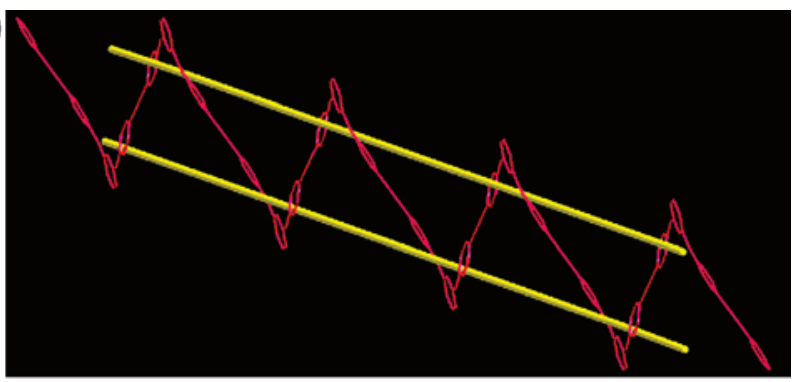

(b)

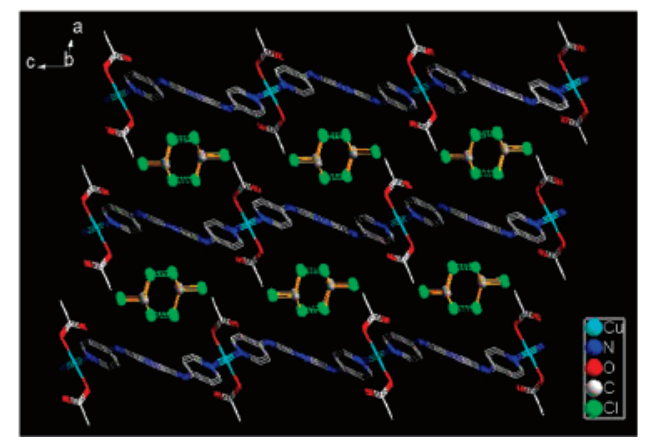

Figure 4. (a) 1D meso-helix structure of compound $\mathbf{2} \cdot \mathbf{C} \mathbf{H C l}_{\mathbf{3}}$, emphasizing (yellow bar) the right- and left-handed helix chains; (b) view of the supramolecular framework of $\mathbf{2} \cdot \mathbf{C H C l}_{\mathbf{3}}$ containing $1 \mathrm{D}$ open channels encapsulating $\mathrm{CHCl}_{3}$ molecules (shown as a ball and stick model).

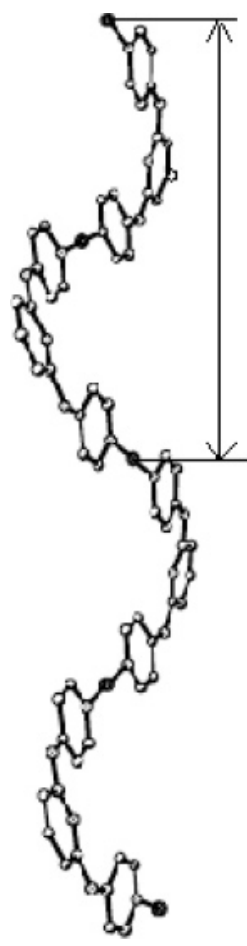

$16.417(4) \AA$

Figure 5. View of a right-handed $2_{1}$ helix chain of $\mathbf{2 \cdot 0 . 5 C \mathbf { H } _ { 3 }} \mathbf{O H}$. The pitch is highlighted.

DMF molecules are found in the channels. Similarly, in DMSO or EtOH solvent, only methanol molecules were found in the channels. The single crystals of the guest-exchanged polymers using the above solvents were characterized by X-ray diffraction. They are the same as that of $\mathbf{2} \cdot \mathbf{0 . 5} \mathbf{C H}_{\mathbf{3}} \mathbf{O H}$, which reveals that the MOFs are not only highly stable but also capable of sizeselective sorption due to the limited channel size. Contrary to a robust framework with hydrophobic cavities, we designed cavities with structural flexibility. It is very significant to select

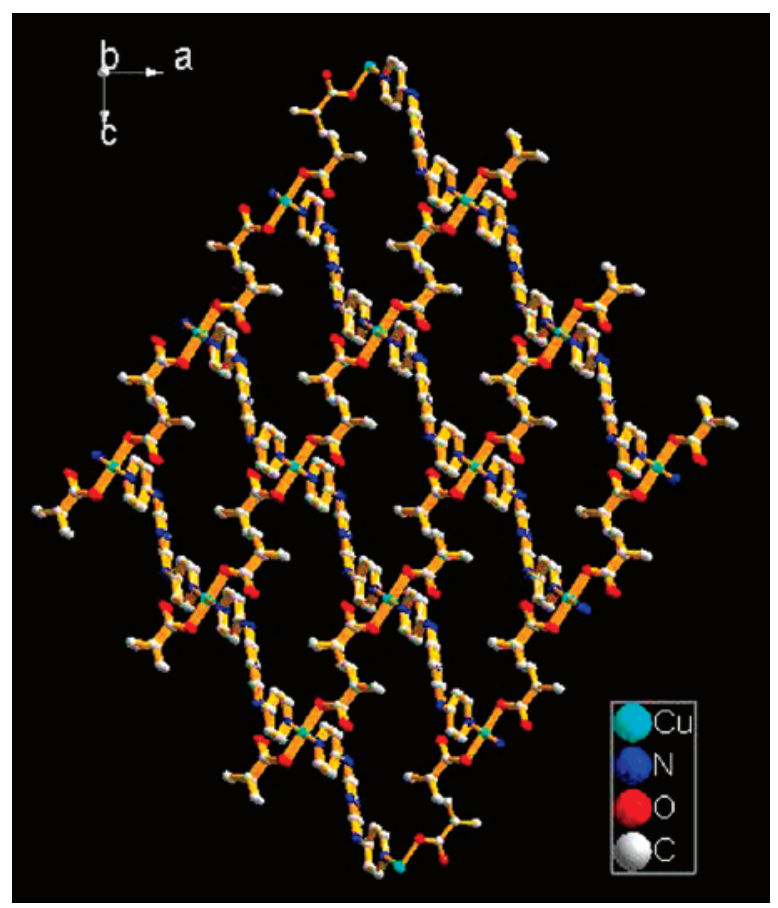

Figure 6. View of the coordination network of $\mathbf{3} \cdot \mathbf{2} \mathbf{C H}_{3} \mathbf{O H}$ down the $b$-axis (solvent molecules are omitted for clarity.)

appropriate, size-fitting guest molecules, which are volatile or exchangeable. ${ }^{20}$ This is indeed successful. By considering the fact that $\mathrm{CH}_{3} \mathrm{CN}, \mathrm{CH}_{2} \mathrm{Cl}_{2}, \mathrm{CHCl}_{3}, \mathrm{CH}_{3} \mathrm{OH}$ are similar both in size and shape and according to the former principle, guest absorption can happen in the channels. Consequently, upon incorporating guest molecules, similar structures are conformed and channels undergo minor conformational changes.

Thermogravimetric Analysis (TGA) and IR Spectra. TGA indicates that $\mathbf{2} \cdot \mathbf{C H}_{\mathbf{3}} \mathbf{C N}$ lost $8.9 \%$ of total weight in the $90-$ $120{ }^{\circ} \mathrm{C}$ temperature range, corresponding to the loss of one $\mathrm{CH}_{3}-$ $\mathrm{CN}$ molecule per formula unit (expected 8.4\%). DSC curve shows an endothermic peak at $110^{\circ} \mathrm{C}$. When the temperature is above $255^{\circ} \mathrm{C}$, the product begins to decompose and oxidize, while the overall observed loss $(74.1 \%)$ is in agreement with the calculated value $(75.2 \%)$, all assigned to the decomposition of dpap ligand and $\mathrm{OAc}^{-}$. The total thermal effect of decomposition and oxidation of ligand causes an exothermic peak at $266.5^{\circ} \mathrm{C}$. The residual percentage weight (observed 17.6\%) at the end of the decomposition of the complex is consistent with the formation of $\mathrm{CuO}$ (expected 16.4\%). The TGA of $\mathbf{2}$. $0.25 \mathrm{CH}_{2} \mathrm{Cl}_{2}$ reveals that the guests $\mathrm{CH}_{2} \mathrm{Cl}_{2}$ are removed in a temperature range of $80-105^{\circ} \mathrm{C}$ and the decomposition of the product observed above ca. $270{ }^{\circ} \mathrm{C}$. Differential scanning calorimetry curve shows an exothermic peak at $278.4^{\circ} \mathrm{C}$, and the residue is $\mathrm{CuO}$ in $15.9 \%$ yield (calculated: $17.1 \%$ ), while $\mathbf{2} \cdot \mathbf{C H C l}_{\mathbf{3}}$ experienced a $20.9 \%$ weight loss in the $80-110{ }^{\circ} \mathrm{C}$ temperature range for one $\mathrm{CHCl}_{3}$ molecule per formula unit (expected $21.2 \%$ ). For $\mathbf{2} \cdot \mathbf{0 . 5} \mathbf{C H}_{3} \mathbf{O H}$, the $\mathrm{CH}_{3} \mathrm{OH}$ molecules are eliminated from the network on raising the temperature to 80$100{ }^{\circ} \mathrm{C}$ (a weight loss of $6.7 \%$ is a little smaller than the calculated value, ${ }^{21} 6.9 \%$ ). $\mathbf{3} \cdot \mathbf{2} \mathbf{C H}_{3} \mathbf{O H}$ experienced a $11.6 \%$ weight loss in the $95-110{ }^{\circ} \mathrm{C}$ temperature range for two $\mathrm{CH}_{3}$ $\mathrm{OH}$ molecules per formula unit (expected $11.3 \%$ ). The decomposition of the organic ligand occurs at $285.8{ }^{\circ} \mathrm{C}$. The residue is $\mathrm{CuO}$, and the observed residue percentages are $13.8 \%$ (calculated: $14.1 \%$ ).

The infrared spectrum of $\mathbf{2} \cdot \mathbf{C H}_{3} \mathbf{C N}, \mathbf{2} \cdot \mathbf{0 . 2 5} \mathbf{C H}_{2} \mathbf{C l}_{2}, \mathbf{2} \cdot \mathbf{C H C l}_{3}$, $2 \cdot 0.5 \mathrm{CH}_{3} \mathrm{OH}$, and $\mathbf{3} \cdot \mathbf{2} \mathrm{CH}_{3} \mathrm{OH}$ exhibit $v_{\text {as }}(\mathrm{OCO})$ and $v_{\mathrm{s}}(\mathrm{OCO})$ 
vibrations of the carboxylate groups at 1577 and $1345 \mathrm{~cm}^{-1}$ for $\mathbf{2} \cdot \mathbf{C H}_{\mathbf{3}} \mathbf{C N}, 1577$ and $1393 \mathrm{~cm}^{-1}$ for $\mathbf{2} \cdot \mathbf{0 . 2 5} \mathbf{C H}_{\mathbf{2}} \mathbf{C l}_{\mathbf{2}}, 1583$ and $1367 \mathrm{~cm}^{-1}$ for $\mathbf{2} \cdot \mathbf{C H C l}_{\mathbf{3}}, 1584$ and $1339 \mathrm{~cm}^{-1}$ for $\mathbf{2} \cdot \mathbf{0 . 5} \mathbf{C H}_{\mathbf{3}} \mathbf{O H}$, and at 1578 and $1368 \mathrm{~cm}^{-1}$ for $\mathbf{3} \cdot \mathbf{2} \mathbf{C H}_{\mathbf{3}} \mathbf{O H}$, respectively. The observed $\Delta v$ in the complexes suggests a monodentate coordination of the carboxylate, ${ }^{22}$ in agreement with the crystallographic structure. In the complex $\mathbf{2} \cdot \mathbf{C H}_{\mathbf{3}} \mathbf{C N}$, the bands appearing at 2100 and $2356 \mathrm{~cm}^{-1}$, can be assigned to the $\mathrm{C} \equiv \mathrm{N}$ stretching frequencies of $\mathrm{CH}_{3} \mathrm{CN}$. Compound $2 \cdot$ $0.25 \mathrm{CH}_{2} \mathrm{Cl}_{2}$ has two bands at about 732 and $677 \mathrm{~cm}^{-1}$, typical of $\mathrm{C}-\mathrm{Cl}$ stretching vibrations. For the complexes $\mathbf{2} \cdot \mathbf{0 . 5} \mathbf{C H}_{\mathbf{3}} \mathbf{O H}$ and $\mathbf{3} \cdot \mathbf{2} \mathbf{C H}_{\mathbf{3}} \mathbf{O H}$, the broad band around $3300 \mathrm{~cm}^{-1}$ can be assigned to the $\mathrm{O}-\mathrm{H}$ stretching vibrations of $\mathrm{CH}_{3} \mathrm{OH}$.

\section{Conclusion}

We have successfully synthesized five closely related coordination polymers generated from a novel flexible ligand dpap in different solvent mixtures. These network superstructures were slightly affected by the incorporation of different solvent molecules and anions, concomitant with an increase or decrease in the channel dimensions. $\mathbf{2} \cdot \mathbf{C H}_{\mathbf{3}} \mathbf{C N}$ displays a zigzag chain propagated along the [011] direction, $\mathbf{2 \cdot \mathbf { 0 . 2 5 }} \mathbf{C H}_{\mathbf{2}} \mathbf{C l}_{\mathbf{2}}$ and $\mathbf{2} \cdot$ $\mathbf{0 . 5} \mathbf{C H}_{3} \mathbf{O H}$ are helices along $[010]$, and $\mathbf{2} \cdot \mathbf{C H C l}_{\mathbf{3}}$ and $\mathbf{3} \cdot$ $\mathbf{2 C H}_{\mathbf{3}} \mathbf{O H}$ exhibit meso-helices down [001] and [101], respectively. Their layers are of the same topology, $(3,4)$ nets with the Schläfli symbol $\left\{4 \cdot 6^{2}\right\} 2\left\{4^{2} \cdot 6^{2}\right\}$. The volumes of the channels

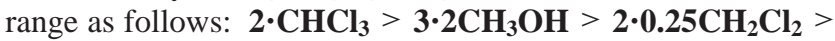
$\mathbf{2} \cdot \mathbf{C H}_{3} \mathbf{C N}>\mathbf{2} \cdot \mathbf{0 . 5} \mathbf{C H}_{3} \mathbf{O H}$. Structural subtle changes in their flexibility allow their predictive general application in crystal engineering, although anions and solvent often have a significant influence on the supramolecular structure.

Acknowledgment. This work was supported by the National Natural Science Foundation of China (No. 20471048) and TRAPOYT, and Specialized Research Fund for the Doctoral Program of Higher Education (No. 20050697005).

Supporting Information Available: Crystallographic information file. This material is available free of charge via the Internet at http:// pubs.acs.org.

\section{References}

(1) (a) Hoskins, B. F.; Robson, R. J. Am. Chem. Soc. 1990, 112, 1546. (b) Yaghi, O. M.; Li, H.; Davis, C.; Richardson, D.; Groy, T. L. Acc. Chem. Res. 2001, 34, 319. (c) Ko, J. W.; Min, K. S.; Suh, P. Inorg. Chem. 2002, 41, 2151. (d) Chen, B.; Eddaoudi, M.; Hyde, S. T.; O'Keeffe, M.; Yaghi, O. M. Science 2001, 291, 1021. (e) Batten, S. R.; Robson, R. Angew. Chem. Int. Ed. 1998, 37, 1460.

(2) (a) Uemura, K.; Kitagawa, S.; Kondo, M.; Fukui, K.; Kitaura, R.; Chang, H. C.; Mizutani, T. Chem. Eur. J. 2002, 8, 3587. (b) Matsuda, R.; Kitaura, R.; Kitagawa, S.; Kubota, Y.; Kobayashi, T. C.; Horike, S.; Takata, M. J. Am. Chem. Soc. 2004, 126, 14063.

(3) (a) Li, H.; Eddaoudi, M.; O'Keeffe, M.; Yaghi, O. M. Nature 1999, 402, 276. (b) Yaghi, O. M.; O'Keeffe, M. N.; Ockwig, W.; Chael, H. K.; Eddaoudi, M.; Kim, J. Nature 2003, 423, 705. (c) Biradha, K.; Hongo, Y.; Fujita, M. Angew. Chem., Int. Ed. 2002, 41, 3395. (d) Biradha, K.; Fjita, M. Angew. Chem., Int. Ed. 2002, 41, 3392.

(4) (a) Fujita, M.; Kwon, J. Y.; Washizu, S.; Ogura, K. J. Am. Chem. Soc. 1994, 116, 1151. (b) Yaghi, O. M.; Li, H. J. Am. Chem. Soc. 1996, 118, 295. (c) Noro, S.-i.; Kitagawa, S.; Kondo, M.; Seki, K. Angew. Chem., Int. Ed. 2000, 39, 2082. (d) Seo, J. S.; Whang, D.;
Lee, H.; Jun, S. I.; Oh, J.; Jeon, J. Y.; Kim, K. Nature 2000, 404, 982.

(5) (a) Chael, H. K;. Siberio-Pe'rez, D. Y.; Kim, J.; Go, Y. B.; Eddaoudi, M.; Matzer, A. J. O'Keeffe, M.; Yaghi, O. M. Nature 2004, 427, 523. (b) Wang, Z.; Zhang, B.; Fujiwara, H.; Kobayashi, H.; Kurmoo, M. Chem. Commun. 2004, 416. (c) Halder, G. J.; Kepert, C. J. J. Am. Chem. Soc. 2005, 127, 7891. (d) Yamada, K.; Yagishita, S.; Tanaka, H.; Tohyma, K.; Adachi, K.; Kaizaki, S.; Kumagai, H.; Kitaura, R.; Chang, H.-C.; Kitagawa, S.; Kawata, S. Chem. Eur. J. 2004, 10, 1.

(6) Buss, C. E.; Anderson, C. E.; Pomije, M. K;. Lutz, C. M.; Britton, D.; Mann, K. R. J. Am. Chem. Soc. 1998, 120, 7783.

(7) Soldatov, D. V.; Henegouwen, A. T.; Enright, G. D.; Ratcliffe, C. I.; Ripmeester, J. A. Inorg. Chem. 2001, 40, 1626.

(8) Hennigar, T. L.; MacQuarrie, D. C.; Losier, P.; Rogers, R. D.; Zaworotko, M. J. Angew. Chem., Int. Ed. 1997, 36, 972.

(9) Withersby, M. A.; Blake, A. J.; Champness, N. R.; Cooke, P. A.; Hubbersty, P.; Li, W.-S.; Schröder, M. Inorg. Chem. 1999, 38, 2259 .

(10) Blake, A. J.; Champness, N. R.; Cooke, P. A.; Nicolson, J. E. B.; Wilson, C. J. Chem. Soc. Dalton Trans. 2000, 3811.

(11) Cordes, D. B.; Hanton, L. R. Inorg. Chem. 2007, 46, 1634.

(12) Sheldrick, G. M. SHELXS, University of Göttingen, Germany, 1997.

(13) Sheldrick, G. M. SHELXL, Program for the Refinement of Crystal Structure, University of Göttingen, Germany, 1997.

(14) Wells, A. F. Three-Dimentional Nets and Polyhedra; WileyInterscience, New York, 1997.

(15) Spek, A. L. PLATON, Utrecht University, Utrecht, The Netherlands, 1998

(16) (a) Luan, X.-J.; Wang, Y.-Y.; Li, D.-S.; Liu, P.; Hu, H.-M.; Shi, Q.-Z.; Peng, S. M. Angew. Chem., Int. Ed. 2005, 44, 3864. (b) Luan, X.-J.; Cai, X.-H.; Wang, Y.-Y.; Li, D.-S.; Wang, C.-J.; Liu, P.; Hu, H.-M.; Shi, Q.-Z.; Peng, S. M. Chem. Eur. J. 2006, 12, 6281.

(17) (a) Son, S. U.; Park, K. H.; Kim, B. Y.; Chung, Y. K. Cryst. Growth Des. 2003, 3, 507. (b) Plasseraud, L.; Maid, H.; Hampel, F.; Saalfrank, R. W. Chem. Eur. J. 2001, 7, 4007. (c) Kondo, M.; Miyazawa, M.; Irie, Y.; Shinagawa, R.; Horiba, T.; Nakamura, A.; Naito, T.; Maeda, K.; Utsunoc, S.; Uchidac, F. Chem. Commun. 2002, 2156. (d) Zhang, L.-J.; Zhan, J.-Q.; Shi, X.; Zhao, X.-L.; Wang, T.G. Chem. Lett. 2002, 1052. (e) Bartlett, R. A.; Olmstead, M. M.; Power, P. P. Inorg. Chem. 1986, 25, 1243. (f) Cai, Y. P.; Zhang, H. X.; Xu, A. W.; Su, C. Y.; Chen, C. L.; Liu, H. Q.; Zhang, L.; Kang, B. S. J. Chem. Soc., Dalton Trans. 2001, 2429.

(18) Zhou, A.-J.; Zheng, S.-L.; Fang, Y.; Tong, M.-L. Inorg. Chem. 2005, $44,4457$.

(19) (a) Eddaoudi, M.; Kim, J.; Wachter, J. B.; Chae, H. K.; O'Keeffe, M.; Yaghi, O. M. J. Am. Chem. Soc. 2001, 123, 4368. (b) Eddaoudi, M.; Li, H.; Yaghi, O. M. J. Am. Chem. Soc. 2000, 122, 1391. (c) Eddaoudi, M.; Moler, D. B.; Li, H.; Chen, B.; Reineke, T. M.; O'Keefe, M.; Yaghi, O. M. Acc. Chem. Res. 2001, 34, 319.

(20) Kitagawa, S.; Kitaura, R.; Noro, S.-i. Angew. Chem., Int. Ed. 2004, 43,2334

(21) Huang, Z.; Song, H.-B.; Du, M.; Chen, S.-T.; Bu, X.-H. Inorg. Chem. 2004, 43, 931.

(22) Deacon, G. B.; Phillips, R. J. Coord. Chem. Rev. 1980, 33, 227.

(23) Mukhopadhyay, S.; Chatterjee, P. B.; Mandal, D.; Mostafa, G.; Caneschi, A.; Slageren, J. V.; Weakley, T. J. R.; Chaudhury, M. Inorg. Chem. 2004, 43, 3413.

(24) Wang, L. Y.; Li, L. C.; Liao, D. Z.; Jiang, Z. H.; Yan, S. P. Eur. J. Inorg. Chem. 2004, 2266.

(25) Fisher, M. E. Am. J. Phys. 1964, 32, 343

(26) Mukherjee, P. S.; Ghoshal, D.; Zangrando, E.; Mallah, T.; Chaudhuri, N. R. Eur. J. Inorg. Chem. 2004, 4675.

(27) Dalai, S.; Mukherjee, P. S.; Rogez, G.; Mallah, T.; Drew, M. G. B.; Chaudhuri, N. R. Eur. J. Inorg. Chem. 2002, 3292.

CG070246G 